UDC 541.128

\title{
HETEROGENEOUS CATALYTIC HYDROGENATION OF CARBON DIOXIDE INTO HYDROCARBONS: ACHIEVEMENTS AND PROSPECTS
}

\author{
${ }^{1}$ Sh.F. Tagiyeva, ${ }^{2}$ E.H. Ismailov \\ ${ }^{1}$ Institute of petrochemical processes, Azerbaijan National Academy of Sciences, \\ AZ1025, 30 Khojaly Ave., Baku, Azerbaijan \\ ${ }^{2}$ Inastitue of Catalysis and Inorganic Chemistry, Azerbaijan National Academy of Sciences, \\ AZ1143, 113 H.Javid Ave., Baku, Azerbaijan \\ E-mail: tshaxla@mail.ru
}

Received 15.10.2020

Accepted 27.12.2020

\begin{abstract}
The works published over the past 10 years on the catalytic hydrogenation of carbon dioxide into methane and $C_{2}$ hydrocarbons are considered. The choice of catalysts based on their elemental and phase composition, structural-porous characteristics, grain-size and acidic properties, the reaction mechanism and problems and prospects for the industrial application of heterogeneous catalytic conversion of $\mathrm{CO}_{2}$ to hydrocarbons are discussed.
\end{abstract}

Keywords: carbon dioxide, hydrogenation, heterogeneous catalysts, methane, $C_{2+}$ hydrocarbons

DOI: $10.32737 / 2221-8688-2020-4-485-500$

\section{Introduction}

Today, there is no doubt that the upward trend in $\mathrm{CO}_{2}$ emissions into the atmosphere since the beginning of industrialization is a key factor in changing the planet's climate over the past two centuries [1,2]. Solutions aimed at mitigating the above problem are based on: a) full and / or partial replacement of carbon fuels with renewable energy sources, b) technologies for capturing and storing carbon dioxide, and c) chemical conversion of $\mathrm{CO}_{2}$ into valuable chemicals and fuels $[3,4]$. The latter approach has attracted a lot of interest in recent decades. Carbon dioxide is a cheap, safe and renewable source of carbon for the production of organic compounds. At the moment, the use of $\mathrm{CO}_{2}$ as a chemical raw material is limited to the synthesis of urea and its derivatives, salicylic acid and carbonates [5]. This is due to the thermodynamic stability of the carbon dioxide molecule and the high endothermicity of its involvement in chemical reactions. Among the methods of processing carbon dioxide $\mathrm{CO}_{2}$, catalytic hydrogenation is one of the most promising [6,7]. The most studied are the photo$[8,9]$, electro- $[10,11]$ and thermocatalytic (the latter is often called simply catalytic) $[12,13]$ variants of $\mathrm{CO}_{2}$ hydrogenation. There are known works in which ionic liquids and supercritical $\mathrm{CO}_{2}$ are used [14-16]. For hydrogenation of $\mathrm{CO}_{2}$, both homogeneous and heterogeneous catalysts are used [17-22]. Homogeneous catalysts exhibit high activity and selectivity in this process, but their recovery and regeneration are problematic. Heterogeneous catalysts are stable, easily regenerated, and are preferred for large-scale production [23, 24].

Hydrogenation of $\mathrm{CO}_{2}$ produces methane, $\mathrm{C}_{2+}$ hydrocarbons, their mixtures, mainly gasolines, as well as methanol, dimethyl ether and a number of other oxygen-containing substances used in the chemical, petrochemical, pharmaceutical, medical, electronic and other industries $[25,26]$. This review considers the works published mainly over the past 10 years on the catalytic hydrogenation of carbon dioxide to methane and $\mathrm{C}_{2+}$ hydrocarbons. 


\section{Methanation of carbon dioxide}

Methanation of carbon dioxide $\left(\mathrm{CO}_{2}+\right.$ $4 \mathrm{H}_{2}=\mathrm{CH}_{4}+2 \mathrm{H}_{2} \mathrm{O}$ ), i.e. the Sabatier reaction is a highly exothermic reaction with the release of $\sim 164 \mathrm{~kJ}$ of heat per mole of $\mathrm{CO}_{2}$. When the ratio $\mathrm{CO}_{2} / \mathrm{H}_{2}=1 / 1$, carbon dioxide is reduced to carbon monoxide $\left(\mathrm{CO}_{2}+\mathrm{H}_{2}=\mathrm{CO}+\mathrm{H}_{2} \mathrm{O}\right)$. The reaction proceeds with heat absorption $\left(\Delta \mathrm{H}_{298}=41.5 \mathrm{~kJ} / \mathrm{mol}\right)$. The main side reaction proceeding in this system and affecting the yield and composition of the resulting products is the Bell-Budard reaction $\left(2 \mathrm{CO}=\mathrm{CO}_{2}+\mathrm{C} ; \Delta \mathrm{H}_{298}=\right.$ - $172.3 \mathrm{~kJ} / \mathrm{mol})$. It increases with increasing temperature and is the reason for the decrease in catalytic activity due to the deposition of carbon on the catalyst surface. The reduction of $\mathrm{CO}_{2}$, in which carbon has the highest oxidation state $(+4)$, occurs with significant kinetic limitations, which require the selection of effective catalysts to achieve acceptable rates and selectivity of the process [27, 28]. In [29-31], thermodynamic analysis was performed to predict the maximum theoretical yield and selectivity of the expected products. $\mathrm{H}_{2}, \mathrm{CO}_{2}, \mathrm{CO}, \mathrm{C}, \mathrm{CH}_{4}$, and $\mathrm{H}_{2} \mathrm{O}$ were considered as the main reaction products.

Mainly mono- and bimetallic systems containing Group VIII metals ( $\mathrm{Fe}, \mathrm{Co}, \mathrm{Ni}, \mathrm{Rh}$, $\mathrm{Pd}, \mathrm{Pt}$ ) have been studied as catalysts for $\mathrm{CO}_{2}$ hydrogenation [32-34]. Nickel and ruthenium deposited on various oxides $\left(\mathrm{SiO}_{2}, \mathrm{TiO}_{2}, \mathrm{Al}_{2} \mathrm{O}_{3}\right.$, $\mathrm{ZrO}_{2}, \mathrm{CeO}_{2}$, etc.) turned out to be the most active catalysts for $\mathrm{CO}_{2}$ methanation. Ni-based catalysts are widely used for industrial purposes due to their low cost. However, the nickel catalyst is deactivated even at sufficiently low temperatures, mainly due to the sintering of $\mathrm{Ni}$ particles and the formation of carbon deposits $[35,36]$. To increase the stability of nickel catalysts, they are modified, the other metals are introduced into them, and the support is changed. $\gamma-\mathrm{Al}_{2} \mathrm{O}_{3}[37,38], \mathrm{SiO}_{2}$ [39-41], $\mathrm{TiO}_{2}$ [42], $\mathrm{CeO}_{2}[43,44], \mathrm{ZrO}_{2}$ [45,46], hydrotalcite [47], various zeolites and carbon materials, including carbon nanotubes, etc. [48-50]. Note that acidity, structural and porous characteristics (surface area, pore volume, and their size distribution) of the support play an important role in determining the properties of catalysts for $\mathrm{CO}_{2}$ methanation [51, 52]. The use of zeolites in the hydrogenation of carbon dioxide to methane shows that zeolite-based catalysts are more active and selective than commercial materials. The information available in the literature shows that, taking into account the well-known properties of zeolites and the possibility of fine modulation of their properties, it is possible to achieve good results in controlling their catalytic properties in the reaction of hydrogenation of $\mathrm{CO}_{2}$ into hydrocarbons by directionally changing its structural and dimensional properties of metal, metal-oxide particles, introduced into the zeolite. The possible correlations between the structural features, acidity and catalytic properties of zeolites are presented and discussed [53]. Effects of crystal phase of supports and metal-support interaction on tuning product distribution are shown in $\mathrm{CO}_{2}$ hydrogenation on unpromoted and $\mathrm{Zr}$, K, Cspromoted $\mathrm{Co} / \mathrm{TiO}_{2}$ Catalysts [54]. In [55], nickel nanoparticles were deposited on yttriumstabilized zirconium oxide (YSZ) obtained by electroplating. The catalytic conversion of carbon dioxide to $\mathrm{CH}_{4}$ was studied on five $\mathrm{Ni} / \mathrm{YSZ}$ samples with the same nickel loading (10 wt\%), but with different sizes of $\mathrm{Ni}$ particles. The results showed that the catalytic activity and selectivity for $\mathrm{CH}_{4}$ depend on the size and morphology of the Ni particles. In [56] $\mathrm{CO}_{2}$ methanation over sponge $\mathrm{Ni}$ was investigated. When $\mathrm{CO}_{2}$ methanation was carried out using sponge $\mathrm{Ni}$ without any pretreatment, the sponge $\mathrm{Ni}$ exhibited a $\mathrm{CO}_{2}$ conversion of $83 \%$ at $250{ }^{\circ} \mathrm{C}$ under a high space velocity $(0.11 \mathrm{~mol}(\mathrm{CO} 2) \mathrm{g}($ cat $)(-1) \mathrm{h}(-1))$. It was suggested that the sponge $\mathrm{Ni}$ is a promising new catalyst for $\mathrm{CO}_{2}$ methanation because it showed the high activity even under the high GHSV, and it is possible to design a small plug flow reactor compared to a conventional reactor, resulting in a low manufacturing cost for the reactor. The high activity can be derived from the great number of crystal defects of fcc-Ni in the sponge $\mathrm{Ni}$. On the other hand, with hightemperature pretreatment, the sponge $\mathrm{Ni}$ lost its activity in $\mathrm{CO}_{2}$ methanation as well as the surface defect sites. The activity loss is explained by the disappearance of the surface defect sites by the high-temperature pretreatment. Ni-CeO $/ 2$ SBA-15-V catalyst was prepared by the impregnation method with 
vacuum thermal treatment and used for $\mathrm{CO}_{2}$ methanation reaction. Compared with $\mathrm{Ni}$ $\mathrm{CeO}_{2} / \mathrm{SBA}-15$-air catalyst with thermal treatment in air, the reduced $\mathrm{Ni}-\mathrm{CeO}_{2} / \mathrm{SBA}-15$ $\mathrm{V}$ catalyst with vacuum thermal treatment exhibited higher $\mathrm{Ni}$ dispersion and smaller $\mathrm{Ni}$ particle size. In $\mathrm{CO}_{2}$ methanation reaction, the $\mathrm{Ni}-\mathrm{CeO}_{2} / \mathrm{SBA}-15-\mathrm{V}$ catalyst was more active and selective than the $\mathrm{Ni}-\mathrm{CeO}_{2} / \mathrm{SBA}-15$-air catalyst. It was suggested that the good activity and selectivity of $\mathrm{Ni}-\mathrm{CeO}_{2} / \mathrm{SBA}-15-\mathrm{V}$ catalyst should be due to highly dispersed $\mathrm{Ni}$ in contact with small $\mathrm{CeO}_{2}$ particles [57]. The works indicated below [58-79] describe nickelcontaining mono-, bi- and more-component catalysts for $\mathrm{CO}_{2}$ methanation with different bases and contents of metal components. In [58] mixed oxides of the $\mathrm{NiO}-\mathrm{CeO}_{2}$ composition with a Ni content in the range of 5-35 wt $\%$ were synthesized using SBA-15 as a matrix and tested in the methanation of $\mathrm{CO}_{2}$. They were found to be highly catalytic in this reaction. It was revealed [59] that a Ni-Co / $\mathrm{ZrO}_{2}-\mathrm{CeO}_{2}$ catalyst prepared by impregnation and coprecipitation methods can achieve $100 \% \mathrm{CO}_{2}$ conversion at a temperature of $\sim 573 \mathrm{~K}$ and $\geq 95 \% \mathrm{CO}_{2}$ conversion at $673 \mathrm{~K}, 99 \%$ selectivity with respect to $\mathrm{CH}_{4}$. The activity of $\mathrm{CO}_{2}$ methanation on nickel-containing catalysts based on $\mathrm{CeO}_{2}$ and $\mathrm{ZrO}_{2}$ in order to optimize the nickel content, its charge state and distribution in the catalyst structure, and the $\mathrm{CeO}_{2} / \mathrm{ZrO}_{2}$ mass ratio to improve the activity and stability of the catalyst in [60] are discussed. The effect of the support on the reducibility, morphology, and dispersion of the active metal during the methanation of $\mathrm{CO}$ and $\mathrm{CO}_{2}$ over $\mathrm{Ni}, \mathrm{Co} / \mathrm{ZrO}_{2}\left(\mathrm{SiO}_{2}, \mathrm{Al}_{2} \mathrm{O}_{3}\right)-\mathrm{CeO}_{2}$ in a catalytic fixed-bed reactor was studied. It has been shown that the binary $\mathrm{ZrO}_{2}-\mathrm{CeO}_{2}$ oxide support promotes the formation of oxygen vacancies, which leads to an increase in the adsorption capacity of $\mathrm{CO}_{2}$ and, hence, to a higher catalytic activity. A catalyst based on $\mathrm{ZrO}_{2}-\mathrm{CeO}_{2}$ can achieve $100 \% \mathrm{CO}$ conversion at $573 \mathrm{~K}$ and $\geq 95 \% \mathrm{CO}_{2}$ conversion at $673 \mathrm{~K}$ is considered in [61]. In [62, 63], a high activity of a Ni-containing catalyst with a base of tetragonal $\mathrm{ZrO}_{2}$ and $\mathrm{W}$ - doped $\mathrm{Ni}-\mathrm{Mg}$ mixed oxide catalyst accordingly for the methanation of $\mathrm{CO}_{2}$ is reported. It was shown in [64] that nickel nanoparticles deposited on $\mathrm{t}-\mathrm{ZrO}_{2}$ have better adsorption of $\mathrm{CO}_{2}$ than those deposited on $\mathrm{m}-\mathrm{ZrO}_{2}$. Zhou et al. [65] prepared Ni-containing catalysts for $\mathrm{CO}_{2}$ methanation based on $\gamma-\mathrm{Al}_{2} \mathrm{O}_{3}$ and studied the effect of $\mathrm{CeO}_{2}$ introduced as an activator on the size, dispersion of nickel particles, their interaction with the substrate, and catalytic properties. $\mathrm{CO}_{2}$ hydrogenation reactions were carried out in a fixed bed reactor at atmospheric pressure. It was found that the introduction of $\mathrm{CeO}_{2}$ into this catalyst leads to a decrease in the particle size of $\mathrm{Ni}$ and, as a result of its interaction with $\mathrm{Al}_{2} \mathrm{O}_{3}$, the amount of $\mathrm{CO}_{2}$ adsorbed on active sites and the conversion of $\mathrm{CO}_{2}$ increased significantly. The productivity of the process has also increased. It was also shown that the samples obtained by various preparation methods differed markedly in structure and catalytic properties. The recent research progresses of constructing highly efficient $\mathrm{Ni}$ based catalysts toward $\mathrm{CO}_{2}$ methanation in the review. Specifically, the strategies on how to enhance the catalytic performances of the $\mathrm{Ni}$ based catalysts have been studied, which include various influencing factors, such as catalytic supports, catalytic auxiliaries and dopants, the fabrication methods, reaction conditions, etc. Finally, the future development trend of the Ni based catalysts is also prospected, which will be helpful to the design and fabrication of the $\mathrm{Ni}$ catalysts with high efficiency toward $\mathrm{CO}_{2}$ methanation process. Comparative studies of iron, nickelcontaining mono and bimetallic catalysts have been carried out, which showed that bimetallic nickel-iron catalysts are more active than monometallic nickel. Research shows that the nature of the second metal has a significant impact on the catalytic activity of the nickel catalyst. Thus, in comparison with $\mathrm{Co}$ and $\mathrm{Cu}$, $\mathrm{Fe}$ noticeably enhances the catalytic activity of $\mathrm{Ni} / \mathrm{ZrO}_{2}$ even at low temperatures [66-69]. The Co-modified $\mathrm{Ni} / \mathrm{SiO}_{2}$ catalysts by coimpregnation with further coprecipitation in the methanation of $\mathrm{CO}_{2}$ is prepared and it was found that these catalysts with an increased amount of Co show a high conversion of $\mathrm{CO}_{2}$ in the temperature range 523-623 $\mathrm{K}$ [70]. Modification of the $\mathrm{Ni} / \mathrm{Al}_{2} \mathrm{O}_{3}$-based catalyst with ruthenium and iron made it possible to obtain promising catalysts for $\mathrm{CO}_{2}$ methanation [71]. In [72] nanosized zirconium dioxide used as a carrier for nickel catalysts is reported. The 
results revealed the dependence of their activity in $\mathrm{CO}_{2}$ methanation on a specific surface area and pore volume of the support.

Figure 1 shows the EMR spectra: a) recorded at room temperature, sample $5 \% \mathrm{Fe}$ $15 \% \mathrm{Ni} / \mathrm{Al}$ oxide catalyst, reduced in a current of
$\mathrm{H}_{2}$ for 1 hour at: 1- 573, $2-673,3-773 \mathrm{~K}$; b) $5 \%$ $\mathrm{Fe}, 15 \% \mathrm{Ni} / \mathrm{Al}$ oxide sample: 3 - calcined in air at $773 \mathrm{~K}$ for 4 hours and recorded at room temperature, 1.2- recorded at $553 \mathrm{~K}$ after holding it at this temperature in a current of $\mathrm{CO}_{2} / \mathrm{H}_{2}$ with a ratio of 1/3 (1) and 1/4 (2) for one hour.
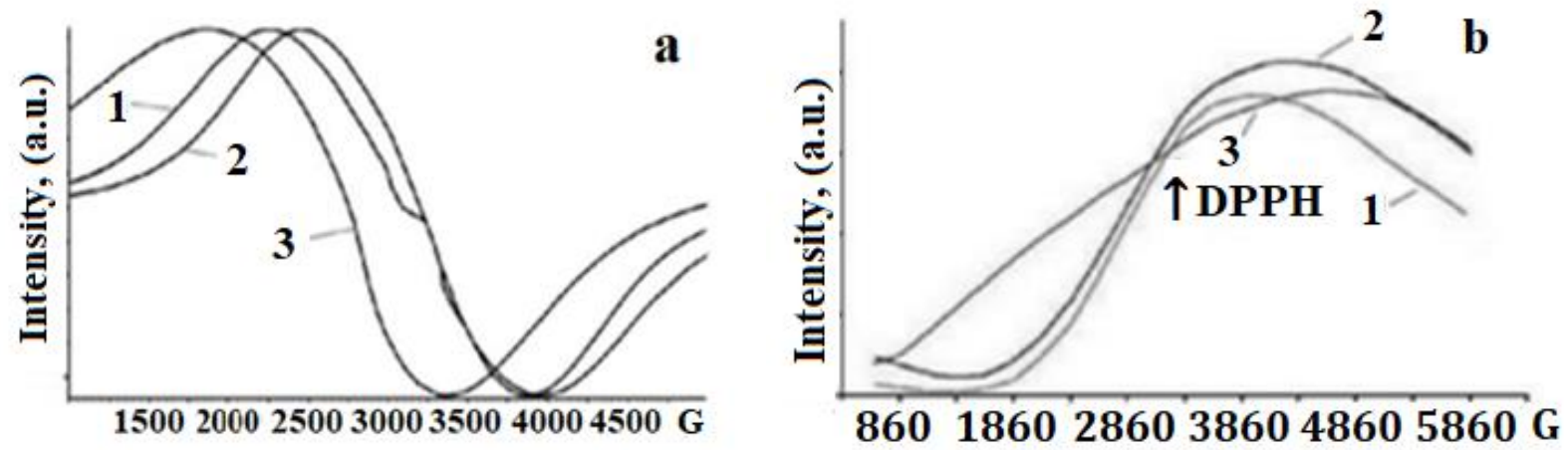

Fig. 1. EMR spectra: a) recorded at room temperature, a sample of $5 \% \mathrm{Fe}-15 \% \mathrm{Ni} / \mathrm{Al}$-oxide catalyst, reduced in a current of $\mathrm{H}_{2}$ for 1 hour at: 1- 573, 2 - 673, $3-773 \mathrm{~K}$; b) $5 \% \mathrm{Fe}, 15 \% \mathrm{Ni} / \mathrm{Al}$ oxide sample: 3 - calcined in air at $773 \mathrm{~K}$ for 4 hours and recorded at room temperature, 1.2recorded at $553 \mathrm{~K}$ after holding it at this temperature in a current of $\mathrm{CO}_{2} / \mathrm{H}_{2}$ with a ratio of $1 / 3$ (1) and $1 / 4$ (2) for one hour.

The EMR spectra shown in Fig. 1, are characteristic to superpara / ferromagnetic particles of $\mathrm{Fe}, \mathrm{Ni}$ - containing catalysts with an oxide base [73, 74]. As seen from Fig. 1, a (curves $1,2,3$ ) and $b$ (curve 3 ), the magnetic characteristics of samples with the same iron and nickel content, first of all, significantly depends on the conditions of their preliminary heat treatment. Secondly, the conditions of the $\mathrm{CO}_{2}$ hydrogenation reaction noticeably affect the magnetic characteristics of these samples.

In figure 2 shows the EMR spectra of the oxide catalyst $5 \% \mathrm{Fe}, 15 \% \mathrm{Zr} / \mathrm{Al}$ (a) and $35 \% \mathrm{Fe}, 15 \% \mathrm{Zr} / \mathrm{Al}$ (b) under the different reaction conditions.
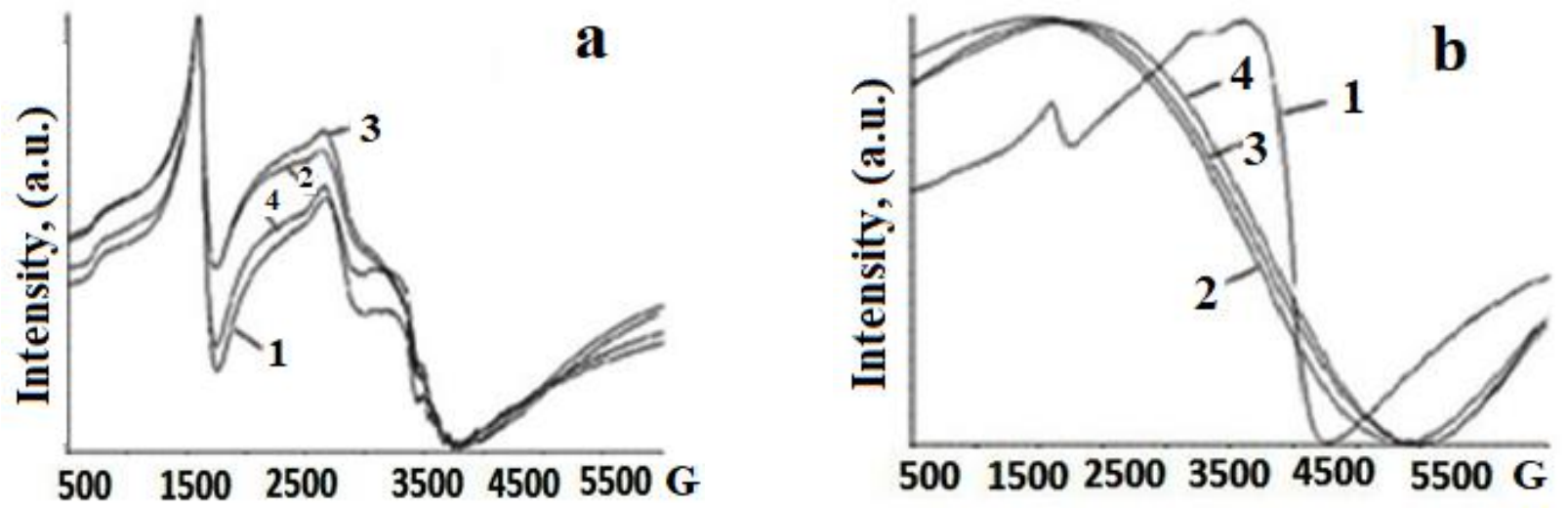

Fig. 2. The EMR spectra of: a) the initial (1) and reduced at 573 (2), 673 (3), and $773 \mathrm{~K}$ (4) samples of $5 \% \mathrm{Fe}, 15 \% \mathrm{Zr} / \mathrm{Al}$ and b) $35 \% \mathrm{Fe}, 15 \% \mathrm{Zr} / \mathrm{Al}: 1$ - calcined in a stream of air for $2 \mathrm{~h}$ at $773 \mathrm{~K} ; 2$, 3,4 - reduced in a current of $\mathrm{H}_{2}$ at 573, 673 and $773 \mathrm{~K}$, respectively. 
The EMR spectrum of a sample of an oxide catalyst $5 \% \mathrm{Fe}, 15 \% \mathrm{Zr} / \mathrm{Al}$, oxidized at $773 \mathrm{~K}$ in an air flow, is a superposition of at least three signals - a wide one with an average g-factor of 2.3 and a width of $\Delta \mathrm{H} \sim 140 \mathrm{mT}$, rather narrow with a g-factor of 4.21 , and a shoulder with $\mathrm{g} \sim 7.2$. Upon restoration, the shape and intensity of this signal noticeably change, splitting into two signals with g-factors of $\sim 2.0$ and 2.9. For the initial sample of the $35 \% \mathrm{Fe}, 15 \% \mathrm{Zr} / \mathrm{Al}$ oxide catalyst oxidized at $773 \mathrm{~K}$ in a flow of air, an EMR spectrum is observed, which consists of a superposition of three signals. The components of this spectrum with $\mathrm{g} \sim 4.21$ are hardly noticeable, the shoulder with $\mathrm{g} \sim 7.2$ is practically not manifested. This spectrum is mainly due to magnetic particles with a g-factor of 2.0 and a width of $\Delta H 110$ mT. Upon restoration, the EMR spectrum of this sample completely changes and is observed in all cases (Fig. 2, b) a wide, slightly asymmetric isotropic signal with average values of the gfactor 2.25-2.42 and width $\Delta \mathrm{H} \sim 290-310 \mathrm{mT}$ depending on the reduction temperature in hydrogen. It can be assumed that the EPR signal observed for samples oxidized at $773 \mathrm{~K}$ in air with a $\mathrm{g}$-factor of 2.0 and a width of $\Delta \mathrm{H} \sim 110$ $\mathrm{mT}$ is due to $\mathrm{Fe}_{2} \mathrm{O}_{3}$ nanoparticles, while an EMR signal with average g-factors of 2.25-2.42

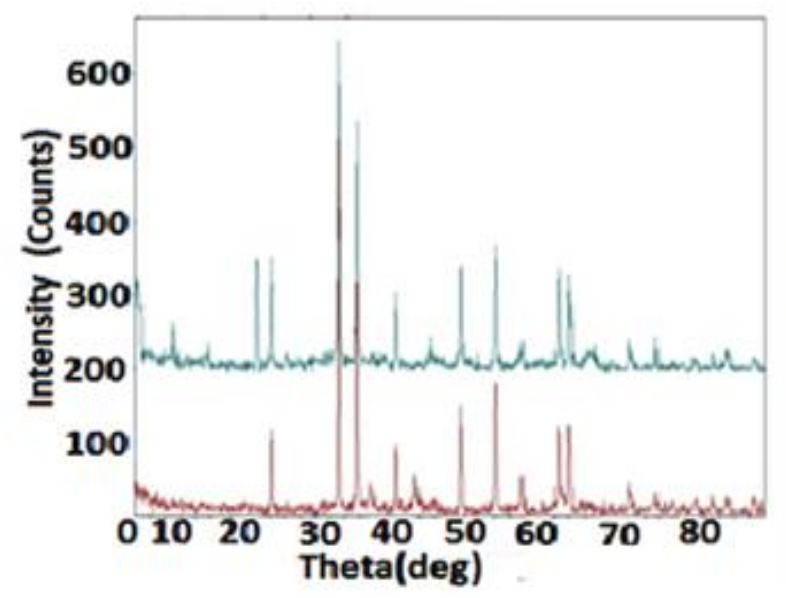

a) and $\Delta \mathrm{H} \sim 290-310 \mathrm{mT}$ width belongs to ferromagnetic particles $\mathrm{Fe}_{3} \mathrm{O}_{4}$. Its appearance is most likely associated with the reduction of a part of $\mathrm{Fe}^{3+}$ iron ions in the original oxide structures of iron to $\mathrm{Fe}^{2+}$ and the formation of oxide structures with a mixed oxidation state of iron such as magnetite $\mathrm{Fe}_{3} \mathrm{O}_{4}$, which, clustering, form magnetically concentrated phases. Note that the intensity of the signal with a g- factor equal to 4.21 and the shoulder with $\mathrm{g} \sim 7.2$ practically does not change when the catalyst is treated in a flow of hydrogen at 573, 673, 773 $\mathrm{K}$, as well as with an increase in the iron content in the samples. This gives grounds to believe that signals with $\mathrm{g}=4.21$ and 7.20 can be attributed to isolated $\mathrm{Fe}^{3+}$ ions in crystal fields of rhombic and axial symmetry, respectively, while resonance with $\mathrm{g} \sim 2.0$ is due to $\mathrm{Fe}^{3+}$ ions associated with exchange interactions in the magnetically concentrated phase [74]. Thus, the experimental data allow us to conclude that the catalysts before and after the methanation reaction contain superpara / ferromagnetic particles, most likely nickel, iron oxides $\mathrm{FeO}_{x}$, possibly also $\mathrm{Ni}_{\mathrm{x}} \mathrm{Fe}_{1-\mathrm{x}} \mathrm{O}_{\mathrm{y}}$. The shape (width, intensity, position in a magnetic field) of the EMR spectra depends on the composition of the samples, the content of iron, nickel (zirconium) in them.

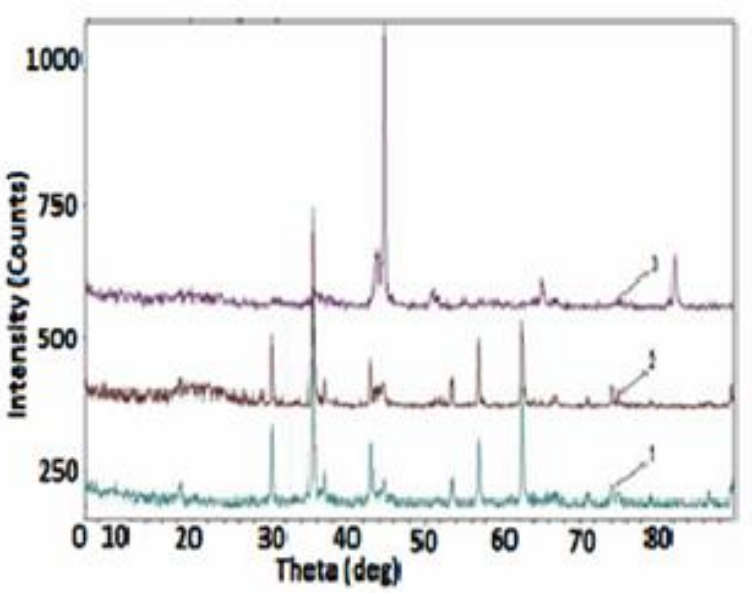

b)

Fig. 3. X-ray diffraction patterns recorded at room temperature: a) $\mathrm{Fe}, \mathrm{Ni} / \mathrm{Al}$ and $\mathrm{Fe}, \mathrm{Zr} / \mathrm{Al}$ oxide catalysts calcined at a temperature of $773 \mathrm{~K}$ in a stream of air; b) catalyst $\mathrm{Fe}, \mathrm{Ni} / \mathrm{Al}$ reduced by hydrogen for 2 hours at: $1-573,2-673,3-773 \mathrm{~K}$.

The magnetic state, phase composition of these catalytic compositions, the dispersion of the active components in them is determined by the conditions of their preliminary heat treatment. However, for some compositions, for example, $\mathrm{Ni}, \mathrm{Ni}-\mathrm{Fe}, \mathrm{Ni}-\mathrm{Co}$ and a number of similar oxide systems, the reaction conditions may change and be different. The magnetic 
properties of these systems can vary from ferromagnetic to superparamagnetic due, most likely, to a change in the particle size, their size distribution in the catalyst structure during its heat treatment in different media and reaction conditions.

The X-ray diffraction patterns of the $\mathrm{Fe}$, $\mathrm{Ni} / \mathrm{Al}_{2} \mathrm{O}_{3}$ oxide catalyst reduced with hydrogen are shown in figure 3.

The given XRD patterns indicate the presence and absence, respectively, of a metallic phase in hydrogen-reduced $\mathrm{Fe}, \mathrm{Ni} / \mathrm{Al}$ and $\mathrm{Fe}$, $\mathrm{Zr} / \mathrm{Al}$ - oxide catalysts. Thus, it can be argued that while the magnetism of the former is due to particles of $\mathrm{Fe}, \mathrm{Ni}$, and $\mathrm{Fe}(\mathrm{Ni}), \mathrm{Fe}(\mathrm{Al})_{2} \mathrm{O}_{4}$, the latter is exclusively due to oxide structures [7375]. It is not possible to say about any connection between the magnetic and catalytic properties of the studied systems in the hydrogenation of $\mathrm{CO}_{2}$ into hydrocarbons. At the same time, both the magnetic and catalytic properties of these systems unambiguously depend on the composition and structuraldimensional, porous characteristics, and what should be especially emphasized, the acid-base properties of the catalysts. The relationship between the magnetic and catalytic properties in this case is not obvious, although it can be easily traced between the catalytic and acid-base properties of catalysts [76-79].

Highly dispersed ruthenium nanoparticles were synthesized by sputtering on a $\mathrm{TiO}_{2}$ support [80]. The prepared $\mathrm{Ru} / \mathrm{TiO}_{2}$ sample catalyzed the methanation reaction at $300 \mathrm{~K}$ at a rate of $0.04 \mu \mathrm{mol} \mathrm{min} \mathrm{mi}^{-1} \cdot \mathrm{g}^{-1}$. At $433 \mathrm{~K}, 100 \%$ yield was observed, i.e. much higher than for a wet impregnated catalyst. The introduction of yttrium into catalysts based on $\mathrm{Ru}$ not only increases the active surface area and dispersion of ruthenium, but also promotes catalytic activity and prevents catalyst deactivation [80]. In [81] $\mathrm{Ru} / \gamma-\mathrm{Al}_{2} \mathrm{O}_{3}$ was used to determine the kinetic parameters of methanation. The activation energy was $82.6 \mathrm{~kJ}$
- $\mathrm{mol}^{-1}$ at $50 \%$ dispersion of ruthenium. The order of reaction with respect to hydrogen decreased with an increase in the $\mathrm{H} / \mathrm{Ru}$ ratio, which may be associated with a change in the heat of hydrogen adsorption and an increase in the number of coordination centers. Highly active and stable $\mathrm{CO}_{2}$ methanation catalyst that was prepared from a Ru-impregnated zirconium-based metal organic framework (MOF) is described in [82]. MOF doped with $\mathrm{Ru}$ is converted under the reaction conditions into an active catalyst that provides $96 \% \mathrm{CO}_{2}$ conversion and $99 \% \mathrm{CH}_{4}$ selectivity. The final catalyst consisted of a mixture of $\mathrm{Ru}$ nanoparticles supported on monoclinic and tetragonal $\mathrm{ZrO}_{2}$ nanoparticles. The mechanism of $\mathrm{CO}_{2}$ methanation over $\mathrm{Rh} / \gamma-\mathrm{Al}_{2} \mathrm{O}_{3}$ catalyst is analyzed in [83]. In [84] the state-of-the-art activation methods and also highlighting similarities in different modes of $\mathrm{CO}_{2}$ activation and correlations to product selectivity to evaluate coherent views on $\mathrm{CO}_{2}$ transformation over catalytic surfaces. $\mathrm{CO}_{2}$ is a thermodynamically stable molecule with the standard formation enthalpy of $-393.5 \mathrm{~kJ} \mathrm{~mol}^{-1}$. However, $\mathrm{CO}_{2}$ can be transformed with notable reactivity depending on the chemical environment. Among them catalysis offers specific sites to activate $\mathrm{CO}_{2}$ for its chemical transformation. There are several activation methods over catalyst surface reported to date and each method generally leads characteristic reactivity of $\mathrm{CO}_{z}$ and products due to the unique form of activated $\mathrm{CO}_{2}$ during transformation. This article describes the main strategies to activate and convert carbon dioxide into valuable chemicals over catalytic surfaces. Coherent elements such as common intermediates are identified in the different strategies and concisely discussed based on the reactivity of $\mathrm{CO}_{2}$ with the aim to understand the decisive factors for selective and efficient $\mathrm{CO}_{2}$ conversion.

\section{Hydrogenation of carbon dioxide to $\mathrm{C}_{2+}$ hydrocarbons.}

Analysis of the literature data showed that to date, noticeable activity in the hydrogenation of carbon dioxide to $\mathrm{C}_{2+}$ hydrocarbons has been established mainly for iron-containing catalysts with an oxide base [85-87]. In [88-90], bimetallic $\mathrm{Fe}-\mathrm{M}(\mathrm{M}=\mathrm{Co}, \mathrm{Ni}, \mathrm{Cu}, \mathrm{Pd})$ catalysts based on $\mathrm{Al}_{2} \mathrm{O}_{3}$, as well as the corresponding monometallic catalysts in the reaction of $\mathrm{CO}_{2}$ hydrogenation to $\mathrm{C}_{2+}$ hydrocarbons, were investigated. It was found that the formation of 
$\mathrm{C}_{2+}$ hydrocarbons is characteristic of ironcontaining catalysts, while the $\mathrm{Co}$ and $\mathrm{Ni}$ catalysts selectively gave higher $\mathrm{CH}_{4}$ yields than other catalysts. The combination of Fe and $\mathrm{Cu}$ or $\mathrm{Pd}$ led to a significant increase in the formation of $\mathrm{C}_{2+}$ hydrocarbons during the hydrogenation of $\mathrm{CO}_{2}$. The $\mathrm{Fe}-\mathrm{Ni}$ bimetallic catalyst is also capable of catalyzing the hydrogenation of $\mathrm{CO}_{2}$ to $\mathrm{C}_{2+}$ hydrocarbons, but at a low $\mathrm{Ni} /(\mathrm{Ni}+\mathrm{Fe})$ atomic ratio. The introduction of a small amount of $\mathrm{K}$ into the $\mathrm{Fe}$ Co catalyst stimulates and noticeably enhances the formation of $\mathrm{C}_{2}-\mathrm{C}_{4}$ olefins, while olefins prevail among $\mathrm{C}_{2+}$ hydrocarbons with an atomic $\mathrm{K} / \mathrm{Fe}$ ratio of 1 . Studies have shown that for the synthesis of $\mathrm{C}_{2}-\mathrm{C}_{4}$ olefins, the $\mathrm{Fe}-\mathrm{Cu}$ catalyst / $\mathrm{K}$ is more preferable than $\mathrm{Fe} / \mathrm{K}, \mathrm{Co} /$ $\mathrm{K}$ and Fe-Mn / K [91-93].

When using a zeolite catalyst, $\mathrm{C}_{2+}$ hydrocarbons of a certain composition were obtained by hydrogenation of carbon dioxide with the use of zeolite and mixed zeolite-oxide systems as catalysts. The dependence of the activity of these catalysts in the hydrogenation of $\mathrm{CO}_{2}$ to methanol and hydrocarbons on the amount of acid sites was studied [94-96]. The $\mathrm{C}_{5}-\mathrm{C}_{11}$ gasoline fraction was obtained with high selectivity on the $\mathrm{In}_{2} \mathrm{O}_{3}$ / HZSM-5 catalyst. The activity of catalysts based on SAPO-5 and SAPO-44 in the hydrogenation of $\mathrm{CO}_{2}$ to $\mathrm{C}_{2+}$ hydrocarbons was established. The synthesis of light alkenes by hydrogenation of carbon dioxide over the bifunctional catalyst $\operatorname{In}_{2} \mathrm{O}_{3} /$ $\mathrm{ZrO}_{2}$-SAPO-34 was studied. It is assumed that methanol is formed on the oxygen vacancies of $\mathrm{In}_{2} \mathrm{O}_{3}$, which is converted into light olefins on the SAPO-34 zeolite. Hydrogenation of $\mathrm{CO}_{2}$ at atmospheric pressure was studied on various catalytic model systems based on $\mathrm{Pd}, \mathrm{Rh}$, and Ni deposited on $\mathrm{SiO}_{2}, \mathrm{Al}_{2} \mathrm{O}_{3}$, and $\mathrm{CeO}_{2}$ oxides and aluminosilicates ZSM-5 and MCM-41 at various specific ratios of reagents and temperatures from 423 to $723{ }^{\circ} \mathrm{C}$. The carrier material and the reaction conditions play an important role in the hydrogenation process. Research results indicate that a metal oxide such as cerium can interact with $\mathrm{CO}$ and promote the hydrogenation reaction by directly forming surface carbonates and formates. $\mathrm{K} / \mathrm{Fe}-\mathrm{Al}-\mathrm{O}$ oxides obtained by coprecipitation in the presence of the surfactant CTAB have shown a significant effect on the performance of catalysts in the hydrogenation of $\mathrm{CO}_{2}$ to hydrocarbons. It was studied the production of light olefins over a $\mathrm{Cu} / \mathrm{Zn} / \mathrm{Zr}$ and SAPO-34 catalyst. The distribution of products was strongly influenced by the ratio of metals, the acidity of the zeolite, and the method of catalyst preparation. The promotion of SAPO-34 with zinc reduced the acidity and led to a sharp limitation of the secondary reactions of the formed olefins. On the $\mathrm{ZnO} / \mathrm{ZrO}_{2}$ and ZSM-5 catalysts, aromatic compounds can be obtained with selectivity up to $70 \%$, while the selectivity for methane is only $1 \%$ [97-101].

The thermodynamics of $\mathrm{CO}_{2}$ hydrogenation into hydrocarbons, the effect of temperature, pressure, and composition of the feedstock on equilibrium conversion were studied in [102]. An increase in temperature above $550 \mathrm{~K}$ negatively affects the equilibrium conversion of $\mathrm{CO}_{2}$ and $\mathrm{H}_{2}$. The temperature is above $750 \mathrm{~K}$ and the pressure is about $30 \mathrm{~atm}$. favorable for the synthesis of heavier hydrocarbons. Analysis of the literature data showed that iron-containing oxide-based catalysts are active in the hydrogenation of carbon dioxide to obtain $\mathrm{C}_{2+}$ hydrocarbons. The activity of these catalysts increases markedly when they are promoted with alkali metals. A disadvantage of iron-containing catalysts is their deactivation due to particle sintering at elevated temperatures and surface carbonization. Cobaltbased catalysts are less active in the synthesis of hydrocarbons from $\mathrm{CO}_{2}$ and hydrogen; on their surface, the reaction of direct methanation, the Sabatier reaction, proceeds [103, 104].

\section{Mechanism of $\mathrm{CO}_{2}$ hydrogenation to hydrocarbons}

Analysis of the currently available data on $\mathrm{CO}_{2}$ hydrogenation suggests that, depending on the operating conditions and the catalyst used, the reaction of $\mathrm{CO}_{2}$ hydrogenation to hydrocarbons proceeds by methanation of $\mathrm{CO}_{2}$ or the formation of $\mathrm{C}_{2+}$ hydrocarbons. It is assumed that the conversion of a mixture of $\mathrm{CO}_{2}$ and $\mathrm{H}_{2}$, for example, into methane, depending on the nature of the active component, can occur either directly or in two stages through the stage of 
carbon monoxide formation [105, 106]. Some studies suggest that monoxide is not involved in $\mathrm{CO}_{2}$ methanation; the mechanism of monoxide hydrogenation is of a different nature [107, 108]. It was shown in [109] that the $3 \% \mathrm{Ru} /$ $\mathrm{Al}_{2} \mathrm{O}_{3}$ catalyst is active in the conversion of $\mathrm{CO}_{2}$ into methane at atmospheric pressure. At $673 \mathrm{~K}$ and above, thermodynamic equilibrium is fully achieved; at $623 \mathrm{~K}$, the yield of $\mathrm{CH}_{4}$ is above $85 \%$. IR studies show that hydrogen-reduced ruthenium catalysts are capable of oxidizing $\mathrm{CO}$ to $\mathrm{CO}_{2}$ at $173-243 \mathrm{~K}$ and the formation of methane from both $\mathrm{CO}$ and $\mathrm{CO}_{2}$ occurs when both surface carbonyl and surface formate structures are observed. $\mathrm{CO}_{2}$ is hydrogenated to methane at $523-573 \mathrm{~K}$, even when no $\mathrm{CO}$ is observed in the gas phase.

The mechanism of the formation of $\mathrm{C}_{2+}$ hydrocarbons during hydrogenation of $\mathrm{CO}_{2}$ is described through the intermediate formation of methanol and without the stage of methanol formation [110, 111]. Hydrogenation of $\mathrm{CO}_{2}$ through intermediate methanol occurs in the presence of mainly copper-zinc catalysts with the formation of light alkanes as the main products with hydrogenation of alkenes [112, 113]. According to the second mechanism, $\mathrm{CO}_{2}$ hydrogenation proceeds in two stages: the stage of the reverse reaction of the conversion of water gas (OCWG) and the Fischer-Tropsch synthesis (FT). Note that, in general, the catalyst components for the synthesis of hydrocarbons from $\mathrm{CO}_{2}$ are the same as for the synthesis of FT. The review [114] presents the progress achieved in recent years in the synthesis of catalysts for the hydrogenation of $\mathrm{CO}_{2}$. In $\mathrm{C}_{2+}$ hydrocarbons, the study of the mechanism of this reaction by combining experimental data and calculations based on the density functional theory (DFT), the factors influencing the performance of the catalysts are indicated, the mechanism of the formation of the $\mathrm{C}-\mathrm{C}$ bond through various routes is given.

\section{Industrial application prospects}

$\mathrm{CO}_{2}$ is currently an important carbon resource for disposal and $\mathrm{CO}_{2}$ hydrogenation is a promising process, especially for methanation. However, $\mathrm{CO}_{2}$ is chemically stable and $\mathrm{CO}_{2}$ methanation is from a thermodynamic point of view an unfavorable process. The most effective catalysts for this reaction are systems based on noble metals such as $\mathrm{Ru}, \mathrm{Rh}$, and $\mathrm{Pd}$, which catalyze the formation of methane under relatively mild conditions. However, their high cost limits their practical application. Therefore, researchers are paying more and more attention to catalysts based on $3 \mathrm{~d}$ - transition metals, mainly $\mathrm{Fe}, \mathrm{CO}$, Ni. A strategy is required to obtain highly efficient catalysts with low temperature methanation and resistance to carbon formation. In addition, it is necessary to understand the detailed mechanism of the functioning of catalysts for methanation of $\mathrm{CO}_{2}$ and to study its dependence on the composition and structure of the catalyst using both theoretical calculations and experimental approaches to develop new effective catalytic systems. It can be assumed that catalysts with a larger surface area and a higher dispersion of the metal component will have higher activity and selectivity and longer stability during $\mathrm{CO}_{2}$ hydrogenation. However, for catalysts, for example, based on nickel, the problem of carbonization is fundamental. As for the technical and economic viability of the $\mathrm{CO}_{2}$ hydrogenation technology, it is important to note the following. Although the capital investment in $\mathrm{CO}_{2}$ hydrogenation technology is similar to the capital investment in conventional syngas technology, the operating costs are unfavorable primarily due to the high hydrogen requirements and the use of significant amounts of electricity. In addition, the cost of $\mathrm{CO}_{2}$ capture also needs to be considered when determining the economic viability of this technology.

\section{Conclusion}

In this review, an attempt is made to summarize the works published, mainly over the past 10 years, on the catalytic hydrogenation of $\mathrm{CO}_{2}$ to hydrocarbons. These studies, first of all, showed that unmodified carriers do not exhibit catalytic activity in the hydrogenation of $\mathrm{CO}_{2}$, which 
indicates the key role of the metals of the 8th group of the Periodic Table. Nickel, iron, ruthenium catalysts, and especially ruthenium catalysts promoted with potassium, exhibit high catalytic activity. The highest activity was observed for carriers that strongly interact with nickel particles, which also indicates a significant role of the properties of the carrier in the activity under hydrogenation conditions. The differences in catalytic activity were likely the result of differences in dispersion and particle size of active metals, as well as interactions between support particles and active metals. These results can be considered primary and, of course, studies of the effect of particle size and their distribution on the activity of catalysts for this reaction will most likely continue. Experiments that discriminate between the size effects of metal particles, such as $\mathrm{Ni}$ and substrate, can provide valuable insights for the development of efficient catalysts for $\mathrm{CO}_{2}$ hydrogenation.

\section{References}

1. Olah, G.A., Prakash, G.K.S. Goeppert, A. Anthropogenic chemical carbon cycle for a sustainable future. J. Am. Chem. Soc. 2011, vol.133, https://doi.org/10.1021/ja202642y

2. Anderson T.R., Hawkins E., Jones P.D. $\mathrm{CO}_{2}$, the greenhouse effect and global warming: from the pioneering work of Arrhenius and Callendar to today's Earth System Models. Endeavour. 2016, vol. 40, pp. 178-187.; doi: 10.1016/j.endeavour.2016.07.002

3. Hunt A.J., Sin E.H.K., Marriott R. and Clark J.H. Generation, capture, and utilization of industrial carbon dioxide. ChemSusChem. 2010, vol.3, pp. 306-322.; https://doi.org/10.1002/cssc.200900169

4. Mikkelsen M., Jorgensen M. and Krebs F.C. The teraton challenge. A review of fixation and transformation of carbon dioxide. Energy Environ. Sci. 2010, vol. 3, pp. 43-81.; https://doi.org/10.1039/B912904A

5. Afanasyev S.V., Sergeev S.P., Volkov V.A. Modern trends in the production and processing of carbon dioxide. Chemical engineering. Interdisciplinary journal for chief specialists of enterprises. 2016, no. 11, pp. 30-33. (In Russian).

6. Ma J., Sun N.N., Zhang X.L., Zhao N., Vao F.K., Wei W., Sun Y.H. A review of the catalytic hydrogenation of carbon dioxide into value-added hydrocarbons. Catalysis Science \& Technology. 2017, vol. 7, pp. 5500-5504.; https://doi.org/10.1039/C7CY01403A

7. Wang W., Wang S., Ma X., Gong J. Recent advances in catalytic hydrogenation of carbon dioxide. Chem. Soc. Rev. 2011, vol. 40, pp.
3703-3727.;

https://doi.org/10.1039/C1CS15008A

8. Tu W., Zhou Y., Zou Z. Photocatalytic conversion of $\mathrm{CO}_{2}$ into renewable hydrocarbon fuels: State-of-the-art accomplishment, challenges, and prospects. Adv. Mater. 2014, vol. 26, pp. 4607- 4626.; https://doi.org/10.1002/adma.201400087

9. Li K., Peng B., Peng T. Recent Advances in Heterogeneous Photocatalytic $\mathrm{CO}_{2}$ Conversion to Solar Fuels. ACS Catal. 2016, vol.6, pp. 7485-7527.; https://doi.org/10.1021/acscatal.6b02089

10. Yamazaki Y., H. Takeda H., Ishitani O. Photocatalytic reduction of $\mathrm{CO}_{2}$ using metal complexes. Journal of Photochemistry and Photobiology C: Photochemistry Reviews. 2015, vol. 25, pp. 106-137. ; doi: 10.1016/j.jphotochemrev.2015.09.001

11. Gonçalves M.R., Gomes A., Condeço J., Fernandes T.R.C., T. Pardal T., Sequeira C. C., et al., Electrochemical conversion of $\mathrm{CO}_{2}$ to $\mathrm{C}_{2}$ hydrocarbons using different ex situ copper electrodeposits. Electrochim. Acta. 2013, vol. 102, pp. 388-392.; https://doi.org/10.1016/j.electacta.2013.04.01 5

12. Li, S.; Xu, Y., Chen, Y.; Li, W., Lin, L., Li, M., Deng, Y., Wang, X., Ge, B., Yang, C., Yao, S., Xie, J., Li, Y., Liu, X., Ma, D. Tuning the Selectivity of Catalytic Carbon Dioxide Hydrogenation over Iridium/Cerium Oxide Catalysts with a Strong Metal Support Interaction. Angew. Chem. Int. Ed. 2017, vol. 56, pp.10761-10765.; DOI: 10.1002/anie.201705002

13. Whang H.S., Lim J., Choi M.S., Lee J., Lee $\mathrm{H}$. Heterogeneous catalysts for catalytic $\mathrm{CO}_{2}$ 
conversion into value-added chemicals. BMC Chemical Engineering, 2019, vol. 1(9), pp.1$19 . \quad$ https://doi.org/10.1186/s42480-0190007-7

14. Xia S-M, Chen K-H, Fu H-C and He L-N. Ionic Liquids Catalysis for Carbon Dioxide Conversion With Nucleophiles. Front. Chem. 2018, vol. 6, 462-468. doi: 10.3389/fchem.2018.00462

15. Pokusaeva Ya. A., Koklin A. E., Lunin V. V., Bogdan V. I. $\mathrm{CO}_{2}$ hydrogenation on $\mathrm{Fe}-$ based catalysts doped with potassium in gas phase and under supercritical conditions. Mendeleev Commun. 2019, vol. 29 (4). pp. 382-384. 16. Evdokimenko N.D., Kim K.O., Kapustin G.I., Davshan N.A., Kustov A.L. Hydrogenation of $\mathrm{CO}_{2}$ over $15 \% \quad \mathrm{Fe} / \mathrm{SiO}_{2}$ Catalyst under Sub- and Supercritical Conditions. Kataliz v promyshlennosti. 2018, vol.18(4), pp. 57-63. (In Russian.) https://doi.org/10.18412/1816-0387-2018-457-63

17. Li Y.N., Ma R., He L., Diao Z.F. Homogeneous hydrogenation of carbon dioxide to methanol. Catalysis Science \& Technology. 2014, vol. 4(6), pp.1498-1512;

18. Scharnagl F.K., Hertrich M.F., Neitzel G., Jackstell R., Beller M. Homogeneous Catalytic Hydrogenation of $\mathrm{CO}_{2}$ to Methanol - Improvements with Tailored Ligands. Advanced Synthesis and Catalysts. 2019, vol. 361, Issue 2, pp. 374-379.

19. Liang X., Li C., Recent advances in methanation catalysts for the production of synthetic natural gas. J. Hydrogen Energy. 2014, vol. 39, pp.18894-18907.

20. Liu M., Yi Y., Wang L., Guo H., Bogaerts A. Review Hydrogenation of Carbon Dioxide to Value-Added Chemicals by Heterogeneous Catalysis and Plasma Catalysis. Catalysts. 2019, vol. 9, pp.275302.

21. Nie X., Jiang X., Zhang A., Ding F., Liu M., Z.Liu, Guo X., Song C.. $\mathrm{ZrO}_{2}$ support imparts suerior activity and stability of $\mathrm{Co}$ catalysts for $\mathrm{CO}_{2}$ methanation. Applied Catalysis B: Environmental. 2018, vol. 220, pp. 397-408.

22. Li. Wenhui, W. Haozhi, J. Xiao, Z. Jie, L. Zhongmin, G. Xinwen and S. Chunshan A short review of recent advances in $\mathrm{CO}_{2}$ hydrogenation to hydrocarbons over heterogeneous catalysts. RSC Adv., 2018, vol. 8, pp.7651-7669

23. Muroyama H., Tsuda Y., Asakoshi T., Masitah H., Okanishi T., Matsui T., Eguchi K., Carbon dioxide methanation over $\mathrm{Ni}$ catalysts supported on various metal oxide $J$. Catal., 2016, vol.343, pp.178-184.

24. Aziz M. A. A., Jalil A. A., Triwahyono S. and Ahmad A. $\mathrm{CO}_{2}$ methanation over heterogeneous catalysts: recent progress and future prospects. Green Chem. 2015, vol. 17, pp. 2647-2663.

25. Ye R.-P., Weibo J.D., Morris G., Argyle D. $\mathrm{CO}_{2}$ hydrogenation to high-value products via heterogeneous catalysis. Nature Communications. 2019, vol. 10(1):5698 DOI: 10.1038/s41467-019-13638-9.

26. Gao J., Liu Q., Gu F., Liu B., Zhong Z., Su F.. Recent advances in methanation catalysts for the production of synthetic natural gas. RSC Adv., 2015, vol. 5, pp. 22759-22776.

27. Zhen W., Li B., Lu G., Ma J. Enhancing catalytic activity and stability for $\mathrm{CO}_{2}$ methanation on Ni\&MOF-5 via control of active species dispersion. Chem. Commun. 2015, vol.5. pp.1728-1731.

28. Guo M, Lu G. The difference of roles of alkaline-earth metal oxides on silica-supported nickel catalysts for $\mathrm{CO}_{2}$ methanation. RSC $A d v$. 2014, vol. 4, pp. 58171-58177.;

29. Ahmad W., Al-Matar, Shawabkeh A.R., Rana A. An Experimental and Thermodynamic Study for Conversion of $\mathrm{CO}_{2}$ to $\mathrm{CO}$ and methane over $\mathrm{Cu}-\mathrm{K} / \mathrm{Al}_{2} \mathrm{O}_{3} . J$. of Environmental Chemical Engineering. 2016, vol. 4, pp. 2725-2735.

30. Swapnesh A., Srivastava V.C., Mall I.D. Comparative Study on Thermodynamic Analysis of $\mathrm{CO}_{2}$ Utilization Reactions. Chem. Eng. Technol. 2014, vol. 37, pp. 17651777.

31. Wang T., Lackner KS., Wright AB. Moisture-swing sorption for carbon dioxide capture from ambient air: a thermodynamic analysis. Phys.Chem.Chem.Phys. 2013, vol.15, pp. 5004-5014.

32. Lu X.P., Gu F.N., Liu Q., Gao J.J., Liu Y.J., Li H., Jia L.H., Xu G.W., Zhong Z.Y., Su F.B. VOx promoted Ni catalysts supported on the modified bentonite for $\mathrm{CO}$ and $\mathrm{CO}_{2}$ methanation. Fuel Processing Technology. 2015, vol. 135, pp. 34-46. 
33. De Vasconcelos B. R., Zhao L., Sharrock P., Nzihou A., Minh D.P.. Catalytic transformation of carbon dioxide and methane into syngas over ruthenium and platinum supported hydroxyapatites. Applied Surface Science, Elsevier. 2016, vol. 390, pp.141-156.

34. Graca I., González L.V., Bacariza M.C.,.Fernandes A., Henriques C., Lopes J.M., Ribeiro M.F. $\mathrm{CO}_{2}$ hydrogenation into $\mathrm{CH}_{4}$ on NiHNaUSY zeolites. Appl.Catal.B Environ. 2014, vol. 147, pp.101-110.

35. Zhu P., Chen Q., Yoneyama Y., Tsubaki N. Nanoparticle modified Ni-based bimodal pore catalysts for enhanced $\mathrm{CO}_{2}$ methanation. $R S C$ $A d v .2014$, vol.4, pp. 64617-64624.

36. Porosoff, M.D. and Chen, J.G. Trends in the catalytic reduction of $\mathrm{CO}_{2}$ by hydrogen over supported monometallic and bimetallic catalysts. Journal of Catalysis, 2013, vol.301, pp.30-37.

37. Garbarino G., Riani P., Magistri L., Busca G. A study of the methanation of carbon dioxide on $\mathrm{Ni} / \mathrm{Al}_{2} \mathrm{O}_{3}$ catalysts at atmospheric pressure. Int. J. Hydrogen Energy. 2014, vol. 3, pp. 911557- 11565.

38. Rahmani S., Rezaei M., Meshkania F.J. Preparation of highly active nickel catalysts supported on mesoporous nanocrystalline $\gamma$ $\mathrm{Al}_{2} \mathrm{O}_{3}$ for $\mathrm{CO}_{2}$ methanation. Ind. Eng. Chem. 2014, vol.20, pp. 1346-1352.

39. Aziz M. A. A., Jalil A. A., Triwahyono, M. W. A. Saad. $\mathrm{CO}_{2}$ methanation over Nipromoted mesostructured silica nanoparticles: Influence of $\mathrm{Ni}$ loading and water vapor on activity and response surface methodology studies. Chem. Eng. J. 2015, vol. 260, pp. 757-764.

40. Aziz M. A. A., Jalil A. A., Triwahyono S., Sidik S. M. Methanation of carbon dioxide on metal-promoted mesostructured silica nanoparticles. Appl. Catal. A. 2014, vol. 486, pp.115-122.

41. Yan X. L., Liu Y., Zhao B. R, Wang Z., Wang Y., Liu C. J. Methanation over $\mathrm{Ni} / \mathrm{SiO}_{2}$ : Effect of the catalyst preparation methodologies. Int. J. Hydrogen Energy. 2013, vol. 38, pp. 2283-2291.

42. Liu L., Li C., Wang F., He S., Chen H., Zhao Y., Wei M., Evans D.G., Duan X. Enhanced low-temperature activity of $\mathrm{CO}_{2}$ methanation over highly-dispersed
$\mathrm{Ni} / \mathrm{TiO}_{2}$ catalyst. Catal. Sci. Technol. 2013, Vol.3, pp.2627-2633

43. Zhou G. H., Liu K., Cui H., Xie Z., Jiao G., Zhang K., Zheng X. Methanation of carbon dioxide over $\mathrm{Ni} / \mathrm{CeO}_{2}$ catalysts: Effects of support $\mathrm{CeO}_{2}$ structure. Int. J. Hydrogen Energy. 2017, vol. 42, pp. 16108-16117.

44. Ratchahat S., Sudoh, M., Suzuki Y., Kawasaki W.,Watanabe R.,Fukuhara C. Development of a powerful $\mathrm{CO}_{2}$ methanation process using a structured $\mathrm{Ni} / \mathrm{CeO}_{2}$ catalyst. J. $\mathrm{CO}_{2}$ Util. 2018, vol.24, 210-219.;

45. Takano H., KirihataY., Izumiya K., Kumagai N., Habazaki H., Hashimoto K. Highly active $\mathrm{Ni} / \mathrm{Y}$ doped $\mathrm{ZrO}_{2}$ catalyst for $\mathrm{CO}_{2}$ methanation. App. Surf. Sci., 2016, vol. 358, pp. 653-663.

46. Jia X., Zhang X., Rui N., Xue Hu., Liu C. Structural effect of $\mathrm{Ni} / \mathrm{ZrO}_{2}$ catalyst on $\mathrm{CO}_{2}$ methanation with enhanced activity. Applied Catalysis B: Environmental. 2019, vol. 244, pp. 159-169. doi.org/10.1016/j.apcatb.2018.11.024

47. Abate S., Barbera K., Deorsola E.G., Bensaid S., Perathoner S., Pirone R., Centi G. Synthesis, Characterization, and Activity Pattern of $\mathrm{Ni}-\mathrm{Al}$ Hydrotalcite Catalysts in $\mathrm{CO}_{2}$ Methanation. Ind. Eng. Chem. Res. 2016, vol. 55, pp. 8299-8308.

48. Graça, I.; Gonzalez, L.; Bacariza, C.; Fernandes, A.; Henriques, C.; Lopes, J.; Ribeiro, M.F. $\mathrm{CO}_{2}$ hydrogenation into $\mathrm{CH}_{4}$ on NiHNaUSY zeolites. Appl. Catal. B Environ. 2014, vol. 147, pp.101-110.

49. Feng Y., Yang W., Chen S., Chu W. Cerium promoted nano nickel catalysts $\mathrm{Ni}-\mathrm{Ce} / \mathrm{CNTs}$ and $\mathrm{Ni}-\mathrm{Ce} / \mathrm{Al}_{2} \mathrm{O}_{3}$ for $\mathrm{CO}_{2}$ methanation. Integr. Ferroelectr. 2014, vol. 151, pp.116125.

50. Wang Y., Xu Y., Liu Q., Sun J., Ji S., Wang Z.J. Enhanced low-temperature activity for $\mathrm{CO}_{2}$ methanation over $\mathrm{NiMgAl} / \mathrm{SiC}$ composite catalysts. Journal of chemical technology and biotechnology. 2020, vol. 94 (12), pp. 3780-378. https://doi.org/10.1002/jctb.6078

51. Frontera P., Macario A., Ferraro M., Antonucci P.L. Supported Catalysts for $\mathrm{CO}_{2}$ Methanation: A Review. Catalysts. 2017, vol. 7, pp. 59-87. doi:10.3390/catal7020059

52. Muroyama H., Tsuda Y., Asakoshi T., Masitah H., Okanishi T., Matsui T., Eguchi 
K. Carbon dioxide methanation over $\mathrm{Ni}$ catalysts supported on various metal oxides. J.Catal. 2016, vol. 343, pp.178-184.

53. Bacariza M.C., Graça I., Lopes J.M., Henriques C. Tuning Zeolite Properties towards $\mathrm{CO}_{2}$ Methanation: An Overview. ChemCatChem. 2019, vol. 11(10), pp. 23882400; doi: 10.1002/cctc.201900229

54. Li W., Zhang G., Jiang X., Liu Y., Zhu J., Ding F., Liu Z., Guo X., Song C. $\mathrm{CO}_{2}$ Hydrogenation on Unpromoted and $\mathrm{M}$ Promoted $\mathrm{Co} / \mathrm{TiO}_{2}$ Catalysts $(\mathrm{M}=\mathrm{Zr}, \mathrm{K}, \mathrm{Cs})$ : Effects of Crystal Phase of Supports and Metal-Support Interaction on Tuning Product Distribution. ACS Catalysis. 2019, vol. 9(4), pp. 2739-2751. https: doi.org/10.1021 /acscatal.8b04720

55. Kesavan J.K., Luisetto I., Tuti S., Meneghini C., Iucci G., Battocchio C., Mobilio S., Casciardi S., Sisto R. Nickel supported on YSZ: The effect of Ni particle size on the catalytic activity for $\mathrm{CO}_{2}$ methanation. Journal of $\mathrm{O}_{2}$ Utilization. 2018, vol. 23. pp. 200-211.

56. Tada S, Ikeda S, Shimoda N, Honma T, Takahashi M, Nariyuki A, Satokawa S. Sponge Ni catalyst with high activity in $\mathrm{CO}_{2}$ methanation. Intern. J. of Hydrogen Energy, 2017, vol.42(51), pp. 30126-30134.; doi: 10.1016/j.ijhydene.2017.10.138

57. Wang L., Liu H., Ye H., ${ }^{1}$ Rong Hu R.,Yang S., Tang G., Li K., Yang Y. Vacuum Thermal Treated Ni-CeO $/$ SBA-15 Catalyst for

$\mathrm{CO}_{2}$ Methanation. Nanomaterials, 2018, vol. 8 (10), pp. 759. doi: 10.3390/nano8100759

58. Andrea Cárdenas-Arenas, Helena Soriano Cortés, Esther Bailón-García, Arantxa DavóQuiñonero, Dolores Lozano-Castelló, Agustín Bueno-López. Active, selective and stable $\mathrm{NiO}-\mathrm{CeO}_{2}$ nanoparticles for $\mathrm{CO}_{2}$ methanation. Fuel Processing Technology. 2021, vol. 212, pp.106637. https://doi.org/10.1016/j.fuproc.2020.106637

59. Tada S. Shimizu T., Kameyama H., Haneda T., Kikuchi R. Ni/CeO ${ }_{2}$ catalysts with high $\mathrm{CO}_{2}$ methanation activity and high $\mathrm{CH}_{4}$ selectivity at low temperatures. Int. J. Hydrog. Energy. 2012, vol. 37, pp. 55275531.; doi: 10.1016/j.ijhydene.2011.12.122

60. Ren J., Qin X., Yang J.Z., Qin Z.F., Guo
H.L., Lin J.Y., Li Z. Fuel Process. Methanation of carbon dioxide over $\mathrm{Ni}-$ $\mathrm{M} / \mathrm{ZrO}_{2}(\mathrm{M}=\mathrm{Fe}, \mathrm{Co}, \mathrm{Cu})$ catalysts: Effect of addition of a second metal. Technol. 2015, vol.137, pp. 204-211.;

61. Li, L. Zhou, Q. Zhu, H. Li. Enhanced methanation over aerogel $\mathrm{Ni}, \mathrm{Co} / \mathrm{Al}_{2} \mathrm{O}_{3}$ catalyst in a magnetic fluidized bed. Ind. Eng. Chem. Res. 2013, vol. 52, pp. 66476654.;

62. Hwang S., Lee J., Hong U.G., Baik J.H., Lim H., Song I.K. Methanation of carbon dioxide over mesoporous $\mathrm{Ni}-\mathrm{Fe}-\mathrm{Ru}-$ $\mathrm{Al}_{2} \mathrm{O}_{3}$ xerogel catalysts: Effect of ruthenium content. J. Ind. Eng. Chem. 2013, vol. 19, pp. 698-703

63. Yan Y., Dai Y., He H., Yu Y., Yang Y. A novel $\mathrm{W}$-doped Ni-Mg mixed oxide catalyst for $\mathrm{CO}_{2}$ methanation. Appl. Catal., B, 2016, vol. 196, pp. 108-116.

64. Li Y.R., Lu G.X. and Ma J. T. Highly active and stable nano $\mathrm{NiO}-\mathrm{MgO}$ catalyst encapsulated by silica with a core-shell structure for $\mathrm{CO}_{2}$ methanation. RSC $A d v$. 2014, 4, pp.17420-17428;

65. Zhou G., Liu H., Cui K., Jia A., Hu G., Jiao Z., Liu Y., Zhang X. Role of surface Ni and $\mathrm{Ce}$ species of $\mathrm{Ni} / \mathrm{CeO}_{2}$ catalyst in $\mathrm{CO} 2$ methanation. Appl. Surf. Sci. 2016, vol. 383, pp. 248-252.; https://doi.org/ 10.1016/ j.apsusc. 2016.04.180

66. Lim J.Y., Gregor J.Mc., Sederman A.J., Dennis J.S. Kinetic studies of $\mathrm{CO}_{2}$ methanation over a $\mathrm{Ni} / \gamma-\mathrm{Al}_{2} \mathrm{O}_{3}$ catalyst. Chem.Eng.Sci. 2016, vol. 141, pp. 28-45.

67. Zhao K., Li Z., Bian L. $\mathrm{CO}_{2}$ methanation and co-methanation of $\mathrm{CO}$ and $\mathrm{CO}_{2}$ over $\mathrm{Mn}$ promoted $\mathrm{Ni} / \mathrm{Al}_{2} \mathrm{O}_{3}$ catalysts. Frontiers of Chemical Science and Engineering, 2016, vol.10(2), pp. 273-280.

68. Atzori L., Cutrufello M.G., Meloni D., Monaci R., Cannas C.,Gazzoli D., Sini M.F., Deiana P., Rombi E. $\mathrm{CO}_{2}$ methanation on hard-templated $\mathrm{NiOCeO}_{2}$ mixed oxides. International Journal of Hydrogen Energy. 2017, vol.42(32), pp. 20689-20702.

69. Xu L., Lian X., Chen M., Cui Y., Wang F., $\mathrm{Li}$ W., Huang B. $\mathrm{CO}_{2}$ methanation over CoNi bimetal-doped ordered mesoporous $\mathrm{Al}_{2} \mathrm{O}_{3}$ catalysts with enhanced low-temperature activities. Intern. Journal of Hydrogen 
Energy. 2018, vol. 43, issue 36, pp. 1717217184.; doi: 10.1016/j.ijhydene.2018.07.106

70. Martínez, J., Hernández, E., Alfaro, S., López Medina, R., Valverde Aguilar, G., Albiter, E., Valenzuela, M.A. High Selectivity and Stability of Nickel Catalysts for $\mathrm{CO}_{2}$ Methanation: Support Effects. Catalysts. 2019, vol. 9, pp. 24-36. doi:10.3390/catal9010024.

71. Golosman E.Z., Efremov V.N. Industrial catalysts for the hydrogenation of carbon oxides. Catalysis in industry, 2012, no. 5, pp. 36-55 (In Russian).

72. Pandey, D., Deo, G. Effect of support on the catalytic activity of $\mathrm{Ni}-\mathrm{Fe}$ catalysts for $\mathrm{CO}_{2}$ methanation reaction.

J. Ind. Eng. Chem. 2016, 33, 99-107.

73. Tagiyeva, S.F., Aliyeva, N.M., Ismailov, E.H. et al. Structure and Magnetic Properties of $\mathrm{Fe}, \mathrm{Ni}(\mathrm{Zr}) / \mathrm{Al}$ Oxide Catalysts Under the Conditions of Methanation of Carbon Dioxide. Theor Exp Chem.,2018, V. 54, pp.274-282. https://doi.org/10.1007/s11237-018-9573-7

74. Sayler R.I., Hunter B.M., Fu W., Gray H.B., Britt R.D.. EPR Spectroscopy of Ironand Nickel-Doped [ZnAl]-Layered Double Hydroxides: Modeling Active Sites in Heterogeneous Water Oxidation Catalysts. $J$. Am. Chem. Soc. 2020, 142, 4, 1838-1845.; https://doi.org/10.1021/jacs.9b10273

75. Meng F., Zhong P., Li Z., Cui X., Zheng H. Surface Structure and Catalytic Performance of Ni-Fe Catalyst for Low Temperature CO Hydrogenation. Journal of Chemistry, 2014, Article

ID 534842 | https://doi.org/10.1155/2014/534 842

76. Zhang Q., Yang X., Guan J. Applications of Magnetic Nanomaterials in Heterogeneous Catalysis. ACS Appl. Nano Mater. 2019, vol. 2, no. 8, pp. 4681- 4697.

77. Sreedhar I., Varun Y., Singh S.A., Venugopal A., Reddy B.M. Developmental trends in $\mathrm{CO}_{2}$ methanation using various catalysts. Catal. Sci. Technol. 2019, vol. 9, pp.4478-4504

78. Lv C., Xu L., Chen M., Cui Y., Wen X., Li Y., Wu C., Yang B., Miao Z., Hu X., Shou Q. Recent Progresses in Constructing the Highly Efficient Ni Based Catalysts With Advanced Low-Temperature Activity
Toward $\mathrm{CO}_{2}$ Methanation. Front. Chem., 28 April 2020 ; https://doi.org/10.3389/fchem.2020.00269

79. Mutz B. H., Carvalho W.P., Mangold S., Kleist W., Grunwaldt J.D. Methanation of $\mathrm{CO}_{2}$ : Structural response of a Ni-based catalyst under fluctuating reaction conditions unraveled by operando spectroscopy. $J$. Catal. 2015, vol. 327, pp. 48-53.

80. Kim A., Sanchez C., Patriarche G., Ersen O., Moldovan S., Wisnet A., Sassoye C. and Debecker D. P. Selective $\mathrm{CO}_{2}$ methanation on $\mathrm{Ru} / \mathrm{TiO}_{2}$ catalysts: unravelling the decisive role of the $\mathrm{TiO}_{2}$ support crystal structure. Catal. Sci. Technol., 2016, vol. 6, pp. 8117-8128.

81._Garbarino G., Bellotti D., Finocchio E., Magistri L., Busca G.. Methanation of carbon dioxide on $\mathrm{Ru} / \mathrm{Al}_{2} \mathrm{O}_{3}$ : catalytic activity and infrared study. Catalysis Today. 2016, vol. 277, pp. 21-28.

82. Lippi R., Howard S.C., Barron H, Easton C.D., Madsen I.C., Waddington L.J., Vogt C., Hill M.R., C. J. Sumby C.J., Doonan C.J. and Kenned D.F.Y. Highly Active Catalyst for $\mathrm{CO}_{2}$ Methanation Derived from a Metal Organic Framework Template. J. of Mater. Chem. A. 2017, vol. 5(25), pp.12990-12997

83. Beuls A., Swalus C., Jacquemin M., Heyen G., Karelovic A., Ruiz P. Methanation of $\mathrm{CO}_{2}$ : Further insight into the mechanism over $\mathrm{Rh} / \gamma-\mathrm{Al}_{2} \mathrm{O}_{3}$ catalyst. Appl.Catal.B Environ. 2012, vol. 113-114, pp. 2-10

84. Alvarez A., Borges M., Olcina J.G., Lingjun Hu., Cornu D., Huang R., Stoian D., Urakawa A. $\mathrm{CO}_{2}$ Activation over Catalytic Surfaces. ChemPhysChem. 2017, vol.18, pp. 3135 - 3141.

85. Fujiwara M., Sakurai H., Shiokawa K., Iizuka Y. Synthesis of $\mathrm{C}_{2+}$ hydrocarbons by $\mathrm{CO}_{2}$ hydrogenation over the composite catalyst of $\mathrm{Cu}-\mathrm{Zn}-\mathrm{Al}$ oxide and $\mathrm{HB}$ zeolite using two-stage reactor system under low pressure. Catalysis Today. 2015, vol. 242, pp. 255-260. doi: 10.1016/j.cattod.2014.04.032

86. Yang H., Zhang C., Gao P., Wang H., Li X., Zhong L., Wei W. and Sun Y. A review of the catalytic hydrogenation of carbon dioxide into value-added hydrocarbons. Catal. Sci. Technol., 2017, vol. 7, pp. 4580-4598. 
87. Zichao Dong, Jie Zhao, Yajie Tian, Bofeng Zhang, $\mathrm{Yu} \mathrm{Wu}$. Preparation and Performances of ZIF-67-Derived FeCo Bimetallic Catalysts for $\mathrm{CO}_{2}$ Hydrogenation to Light Olefins. Catalysts. 2020, vol. 10 (4), pp. 455.

https://doi.org/10.3390/catal10040455

88. Wang H., Zhao Y., Wu Y.,Li R., Zhang H., Yu B., Zhang F., Xiang J., Wang Z., Liu Z. Hydrogenation of Carbon Dioxide to $\mathrm{C}_{2}$ $\mathrm{C}_{4}$ Hydrocarbons Catalyzed by $\mathrm{Pd}\left(\mathrm{PtBu}_{3}\right)_{2}-$ $\mathrm{FeCl}_{2}$ with Ionic Liquid as Cocatalyst. ChemSusChem, 2019, vol. 12 (19), 4390 4394. https://doi.org/10.1002/cssc.201901820

89. Yuan F., Zhang G., Zhu J., Ding F., Zhang A., Song C., Guo X. Boosting light olefin selectivity in $\mathrm{CO}_{2}$ hydrogenation by adding $\mathrm{Co}$ to $\mathrm{Fe}$ catalysts within close proximity. Catalysis Today. 2020, https://doi.org/10.1016/j.cattod.2020.0 7.072

90. Guo Y., Li J., Cui Y., Kosol R., Zeng Y., Liu G., Wu J., Zhao T., Yang G., Shao L., Zhan P., Chen J., Tsubaki N. Spinel-structure catalyst catalyzing $\mathrm{CO}_{2}$ hydrogenation to full spectrum alkenes with an ultra-high yield. Chemical Communications. 2020, vol. 56 (65), pp. 93729375. https://doi.org/10.1039/D0CC03426F

91. Kim K.Y., Lee H., Noh W.Y., Shin J., Han S.J., Kim S.K., An K., Lee J.S. Cobalt Ferrite Nanoparticles to Form a Catalytic Co-Fe Alloy Carbide Phase for Selective $\mathrm{CO}_{2}$ Hydrogenation to Light Olefins. ACS Catalysis. 2020, vol. 10 (15), pp. 8660-8671. https://doi.org/10.1021/acscatal.0c01417

92. Satthawong R., Koizumi N., Song C., Prasassarakich P. Comparative Study on CO2 Hydrogenation to Higher Hydrocarbons over Fe-Based Bimetallic Catalysts. Topics in Catalysis. 2013, vol. 57(6-9), pp. 588-594.

93. Wang $\mathrm{X}$., Song $\mathrm{C}$. $\mathrm{Fe}-\mathrm{Cu}$ Bimetallic Catalysts for Selective $\mathrm{CO}_{2}$ Hydrogenation to Olefin-Rich $\mathrm{C}_{2}{ }^{+}$Hydrocarbons. Industrial \& Engineering Chemistry Research. 2018, vol. 57(13), pp. 4532-4542.

94. Ramirez A., Chowdhury A.D., Dokania A., Cnudde P., Caglayan M., Yarulina I., Hamad E.A., Gevers L., Chikh S.O., De Wispelaere K., V. van Speybroeck and Jorge Gascon. Effect of Zeolite Topology and Reactor
Configuration on the Direct Conversion of $\mathrm{CO}_{2}$ to Light Olefins and Aromatics. ACS Catal. 2019, vol. 9, pp. 6320-6334.

95. Liang B., Ma J., Su X., Yang C., Duan H., Zhou H., Deng S., Li L and Huang Y. Investigation on Deactivation of $\mathrm{Cu} / \mathrm{ZnO} / \mathrm{Al}_{2} \mathrm{O}_{3}$ Catalyst for $\mathrm{CO}_{2}$ Hydrogenation to Methanol. Ind. Eng. Chem. Res. 2019, vol. 58(21), pp. 9030-9037.

96. Li C., Fujimoto K., Yuan X. Direct synthesis of LPG from carbon dioxide over hybrid catalysts comprising modified methanol synthesis catalyst and $\beta$-type zeolite , 2014 Applied Catalysis A General 475:155-160;

DOI: 10.1016/j.apcata.2014.01.025

97. Ramirez A., Bhishek A., Chowdhury D., Caglayan M., Rodriguez-Gomez A., Wehbe N., Abou-Hamad E., Gevers L., Ould-Chikh S., Gascon J. Coated sulfated zirconia/SAPO-34 for the direct conversion of $\mathrm{CO}_{2}$ to light olefins. Catalysis Science \& Tech. 2020, vol. 10 (5), pp. 1507-1517.

98. Dang S., Li S., Yang C., Chen X., Li X., Zhong L., Gao P., Sun Y. Selective Transformation of $\mathrm{CO}_{2}$ and $\mathrm{H}_{2}$ into Lower Olefins over $\mathrm{In}_{2} \mathrm{O}_{3} \quad-\mathrm{ZnZrOx} / \mathrm{SAPO}-34$ Bifunctional Catalysts. ChemSusChem. 2019, vol. 12, pp. 3582-3591.

99. Gao P., Li S., Bu X., Dang S., Liu Z., Wang H., Zhong L., Qiu, Cai J., Wei W. \& Sun Y. Direct conversion of $\mathrm{CO}_{2}$ into liquid fuels with high selectivity over a bifunctional catalyst. Nature Chemistry. 2017, vol. 9, pp. 1019-1024.

100. Roy S., Cherevotan A., and Peter S.C. Thermochemical $\mathrm{CO}_{2}$ Hydrogenation to Single Carbon Products: Scientific and Technological Challenges. ACS Energy Lett. 2018, vol. 3, pp. 1938-1966.

101. Gao J., Jia C. and Liu B. Direct and selective hydrogenation of $\mathrm{CO}_{2}$ to ethylene and propene by bifunctional catalysts. Catal. Sci. Technol., 2017, vol.7, pp. 56025607.

102. Rhodri E. O., O'Byrne J.P., Mattia D., Sofia I. P., Plucinski P and Matthew D. J. Cobalt catalysts for the conversion of $\mathrm{CO} 2$ to light hydrocarbons at atmospheric pressure. Chemical Communications. 2013, vol. 49, pp. 11683-11685. doi: $10.1039 / \mathrm{c} 3 \mathrm{cc} 46791 \mathrm{k}$. 
103. Murciano L.T., Mattia D., D.Jones M., Plucinski P. Formation of hydrocarbons via $\mathrm{CO}_{2}$ hydrogenation - A thermodynamic study. Journal of $\mathrm{CO}_{2}$ Utilization. 2014, vol. 6, pp. 34-39. doi: 10.1016/j.jcou.2014.03.002

104. Liu, X.; Wang, M.; Zhou, C.; Zhou, W.; Cheng, K.; Kang, J.; Zhang, Q.; Deng, W.; Wang, Y., Selective Transformation of Carbon Dioxide into Lower Olefins with a Bifunctional Catalyst Composed of $\mathrm{ZnGa}_{2} \mathrm{O}_{4}$ and SAPO-34. Chem. Commun. 2018, 54 (2), 140-143.

105. Cheng, Q., Tian, Y., Lyu, S. et al. Confined small-sized cobalt catalysts stimulate carbon-chain growth reversely by modifying ASF law of Fischer-Tropsch synthesis. Nature Communications. 2018, vol. 9 , 32503259 . https://doi.org/10.1038/s41467-018-057558

106. Vogt C., Monai M., Sterk E.B., Palle J., Melcherts A. E. M., Zijlstra B., Groeneveld E., Berben P.H., Boereboom J.M., Hensen E. J. M., Meirer F., Filot I. A. W \& Weckhuysen B. M. Understanding carbon dioxide activation and carbon-carbon coupling over nickel. Nature Communications. 2019, vol. 10, pp. 53305340. https://doi.org/10.1038/s41467-01912858-3

107. Saeidi S., Najari S., Fazlollahi F., Nikoo M.K., F.Sefidkon, Klemeš J.J, Baxter L.L. Mechanisms and kinetics of $\mathrm{CO}_{2}$ hydrogenation to value-added products: $\mathrm{A}$ detailed review on current status and future trends. Renewable and Sustainable. Energy Reviews. 2017, vol. 80, pp. 1292-1311.

108. Frei M.S., Cortada M.C., Muelas R.G., Mondelli C., López N., Stewart J.A., Ferré D.C., Ramírez J.P. Mechanismand microkinetics of methanol synthesis via
$\mathrm{CO}_{2}$ hydrogenation on indium oxide. Journal of Catalysis. 2018, 361. pp. 313321.doi.org/10.1016/j.jcat.2018.03.014

109. Jalama K. Carbon dioxide hydrogenation over nickel-, ruthenium-, and copper-based catalysts: Review of kinetics and mechanism. Journal Catalysis Reviews Science and Engineering, 2017, vol.59(2), pp.95-164.; https://doi.org/ 10.1080/01614940.2017.1316172.

110. Qaderi J. A Brief Review on the Reaction Mechanisms of $\mathrm{CO}_{2}$ Hydrogenation into Methanol. International Journal of Innovative Research and Scientific Studies. 2020, vol. 3(2), pp. 53-63. https://ssrn.com/abstract $=3597306$

111. Martin N.M., Velin P., Skoglundh M., M. Bauer and Carlsson P.A. Catalytic hydrogenation of $\mathrm{CO}_{2}$ to methane over supported $\mathrm{Pd}, \mathrm{Rh}$ and Ni. Catal. Sci. Technol. 2017, vol. 7, pp. 1086-1094. https://doi.org/10.1039/C6CY02536F

112. Samanta A., Landau M.V., VidrukNehemya R., Herskowitz M. $\mathrm{CO}_{2}$ hydrogenation to higher hydrocarbons on $\mathrm{K} / \mathrm{Fe}-\mathrm{Al}-\mathrm{O}$ spinel catalysts promoted with $\mathrm{Si}, \mathrm{Ti}, \mathrm{Zr}, \mathrm{Hf}, \mathrm{Mn}$ and Ce. Catal. Sci. Technol., 2017, vol. 7, pp. 4048-4063. https://doi.org/10.1039/C7CY01118K

113. Chen J., Wang X., Wu D., Zhang J. Hydrogenation of $\mathrm{CO}_{2}$ to light olefins on (Zn-)SAPO-34 catalysts: Strategy for product distribution. Fuel, 2019, vol. 239, pp.

https://doi.org/10.1016/j.fuel.2018.10.148

114. Tong M., Hondo E., Chizema L. G., Du C., Ma Q., Mo S., Lu C., Lu P. and Tsubaki N. Hydrogenation of $\mathrm{CO}_{2}$ to $\mathrm{LPG}$ over $\mathrm{Cu}-\mathrm{Zn}$ $\mathrm{Zr} / \mathrm{MeSAPO}-34$ catalysts. New J. Chem., 2020, vol. 44, pp. 9328-9336. https://doi.org/10.1039/D0NJ00907E

\title{
ГЕТЕРОГЕННОЕ КАТАЛИТИЧЕСКОЕ ГИДРИРОВАНИЕ ДИОКСИДА УГЛЕРОДА В УГЛЕВОДОРОДЫ: ДОСТИЖЕНИЯ И ПЕРСПЕКТИВЫ
}

\author{
${ }^{1}$ Ш. Ф. Тагиева, ${ }^{2} Э$. Г. Исмаилов
}

${ }^{1}$ Институт нефтехимических процессов Национальной Академии Наук Азербайджана AZ 1025 Баку, пр.Ходжсаль, 30 


\title{
${ }^{2}$ Институт катализа и неорганической химии Национальной академии наук Азербайджана AZ1143 Баку, пр.Г.Джавида, 113 \\ e-mail: tshaxla@mail.ru
}

Рассмотрены опубликованные за последние 10 лет работы по каталитическому гидрированию диоксида углерода в метан и углеводороды $C_{2+}$. Обсуждаются выбор катализаторов по элементному и фазовому составу, структурно-пористым характеристикам, гранулометрическим и кислотным свойствам, механизму реакиии, а также проблемы и перспективы промышленного применения гетерогенно-каталитической конверсии $\mathrm{CO}_{2}$ в углеводороды.

Ключевые слова: диоксид углерода, гидрирование, гетерогенные катализаторы, метан, углеводороды $C_{2+}$.

\section{KARBON DİOKSIDIN KARBOHIDROGENLORӘ HETEROGEN KATALITIK HIDROGENLOŞMOSİ: NAILIYYYTLOR Və PERSPEKTIVLOR}

\author{
${ }^{1}$ Sh.F.Tă̆gyeva, ${ }^{2}$ E.H.İsmayılov \\ ${ }^{1}$ AMEA akad.Y.Mammadaliyev adina Neft-Kimya Proseslari Institutu \\ AZ1025, Bakl, Xocalı prosp.,30 \\ ${ }^{2}$ AMEA akad.M.Nağtyev adına Kataliz vo Qeyri-üzvi kimya İnstitutu \\ AZ1143, Bakl, H.Cavid prosp. 113 \\ e-mail:tshaxla@mail.ru
}

Son 10 ilda karbon dioksidin metan va $C_{2+}$ karbohidrogenlara katalitik hidrogenlaşmasina aid naşr olunmuş asarlarin təhlili verilir. Element, faza tərkibi, quruluş-məsamə xüsusiyyatlari, ölçü va turş xassalori, reaksiya mexanizmi baxımından katalizatorların seçimi, hamçinin $\mathrm{CO}_{2}$-nin karbohidrogenlaro heterogen katalitik çevrilmasi prosesinin sənayedə tatbiqinin problem va perspektivlari müzakira olunur.

Açar sözlar: karbon dioksid, hidrogenlaşmə, heterogen katalizator, metan, $C_{2+}$ karbohidrogenlar 